\title{
Application of Glow Discharge Mass Spectrometry for the Monitoring of Dopant Distribution in Optical Crystals Grown by TSSG Method
}

\author{
Anna Gubal ${ }^{1}$, Victoria Chuchina ${ }^{1}$, Ivan Trefilov ${ }^{1}$, Oleg Glumov ${ }^{1}$, Viktor Yakobson ${ }^{2}$, \\ Alexander Titov ${ }^{2}$, Nikolay Solovyev ${ }^{1,3, *(D)}$ and Alexander Ganeev ${ }^{1,4}$ \\ 1 St. Petersburg State University, Institute of Chemistry, 199034 St. Petersburg, Russia; \\ a.r.gubal@spbu.ru (A.G.); v.chuchina@spbu.ru (V.C.); ivan.trefilov97@mail.ru (I.T.); \\ glumov@yahoo.com (O.G.); ganeevaa@lumex.ru (A.G.) \\ 2 Joint Stock Company "Research and Production Corporation S.I. Vavilova", 192171 St. Petersburg, Russia; \\ jacobson@goi.ru (V.Y.); alextitov57@mail.ru (A.T.) \\ 3 Institute of Technology Sligo, Ash Lane, F91 YW50 Sligo, Ireland \\ 4 Institute of Toxicology of Federal Medico-Biological Agency, 192019 St. Petersburg, Russia \\ * Correspondence: solovyev.nikolay@itsligo.ie
}

Received: 27 April 2020; Accepted: 15 May 2020; Published: 1 June 2020

\begin{abstract}
Direct analysis of matrix and admixture elements in non-conducting crystals is a relevant analytical task in terms of quality assurance of optical materials. The current study aimed to develop a method capable to assess the inhomogeneity of optical crystals with sufficient sensitivity. $\mathrm{K}_{1-\mathrm{x}} \mathrm{Rb}_{\mathrm{x}} \mathrm{TiOPO}_{4}(\mathrm{x}=0.002$ and 0.05$)$ and $\mathrm{KGd}_{1-\mathrm{y}} \mathrm{Nd}_{\mathrm{y}}\left(\mathrm{WO}_{4}\right)_{2}(\mathrm{y}=0.05)$ were grown using the top-seeded solution growth method (TSSG). The samples were analyzed by microsecond direct current pulsed glow discharge time-of-flight mass spectrometry ( $\mu$ s-PDC TOF GDMS). The data were compared with the results obtained by scanning electron microscope-energy dispersive X-ray spectroscopy (SEM EDX) and spectrophotometry and validated by the analysis of certified reference material. Sample glow discharge sputtering and analysis were optimized and implemented in real samples. Sample coating with a silver layer and sample pressing in the metallic matrix were proposed to ensure effective sputtering for $\mathrm{K}_{1-\mathrm{x}} \mathrm{Rb}_{\mathrm{x}} \mathrm{TiOPO}_{4}$ and $\mathrm{KGd}_{1-\mathrm{y}} \mathrm{Nd}_{\mathrm{y}}\left(\mathrm{WO}_{4}\right)_{2}$, respectively. Using the designed method, the inhomogeneity of the dopant's distribution was demonstrated along the growth axis and in the case of $\mathrm{K}_{1-x} \mathrm{Rb}_{x} \mathrm{TiOPO}_{4}$, also in the growth sectors of different faces. The designed method is applicable for the direct analysis of optical crystal and may be implemented in quality assurance in the manufacturing of optical materials.
\end{abstract}

Keywords: single crystal; stoichiometry; optical materials; glow discharge mass spectrometry

\section{Introduction}

Optical single crystals are widely used in laser optics as laser generators, frequency multiplier, electro-optical shutters, etc. [1]. In the growing of optical single crystals, there are different effects causing inhomogeneous distribution of matrix elements, admixtures, and dopants in the crystal volume [2-4]. In particular, this is the case for crystals originating from the top-seeded solution growth method (TSSG) [2]. In the current study, we considered two types of TSSG-grown crystals: $\mathrm{K}_{1-\mathrm{x}} \mathrm{Rb}_{\mathrm{x}} \mathrm{TiOPO}_{4}$ and $\mathrm{KGd}_{1-\mathrm{y}} \mathrm{Nd}_{\mathrm{y}}\left(\mathrm{WO}_{4}\right)_{2}$ [5-7]. By varying the growth conditions and chemical composition of the initial growth charge by introducing the dopants, materials with the required properties can be obtained [8,9].

$\mathrm{KGd}_{1-\mathrm{y}} \mathrm{Nd}_{\mathrm{y}}\left(\mathrm{WO}_{4}\right)_{2}$ crystals are widely used as solid-state laser sources [10-12]. They are used for the generation and amplification of pulsed near-infrared range lasers. These crystals have effective 
cubic nonlinearity, low excitation threshold, high excitation cross-section, and wide absorbance spectrum [5,13]. To ensure the optimal laser properties of $\mathrm{KGd}_{1-\mathrm{y}} \mathrm{Nd}_{\mathrm{y}}\left(\mathrm{WO}_{4}\right)_{2}$, the mass fraction of $\mathrm{Nd}^{3+}$ doping should be maintained in the range of $\mathrm{y}=0.03-0.08$ [14]. The concentration of the dopant differs in the melt solution and the crystal; thus, the dopant may be inhomogeneously distributed in the crystal volume $[2-4,10,15]$.

Pure and doped $\mathrm{KTiOPO}_{4}$ (KTP) crystals have high quadratic nonlinear susceptibility and electro-optical coefficient $[9,16,17]$. Currently, these crystals are mainly employed for the second-harmonics generation in laser setups. Additionally, such crystals have ferroelectric, pyroelectric, and superionic properties and high laser resistivity [16,18-20]. The defect mechanisms and distribution coefficient for trivalent and tetravalent ions in the family of KTP crystals were described and calculated by Morris et al. [21,22].

In multiple studies $[7,14,23,24]$, the relations between growth rate and the direction of the crystallographic axis were considered, indicating that controlling oversaturation and growth factors yields crystals of the required quality. However, when optimizing the growth conditions of novel crystals or implementation of new dopants, the growth-affecting factors may vary significantly. Thus, the monitoring of growth and dopants' concentration as well as the distribution of matrix and admixture components should be undertaken [2-4].

Nowadays, X-ray-based techniques, such as X-ray fluorescence (XRF) and scanning electron microscope-energy dispersive X-ray spectroscopy (SEM EDX) $[15,25,26]$, are most frequently used to assess the composition of crystals. These techniques are capable of direct analysis of the crystals; however, they are limited by relatively high limits of detection (LoDs) and high matrix effects for many elements. Such techniques as electrothermal atomic absorption spectrometry (ETAAS) and the inductively coupled plasma atomic emission spectrometry (ICP-AES) can be used for the monitoring of impurities and distribution of doped components [4,27]. However, these techniques require the preliminary dissolution of the samples, which is labor-intensive and may cause uncontrollable uncertainty in the measurements. Laser ablation inductively coupled plasma mass spectrometry (LA-ICP-MS) offers prospective approaches for direct solid sample analysis [28,29]. Nevertheless, this method also may be prone to matrix effects, which complicates the calibration and reliable quantification. Instrumental neutron activation analysis (INAA) can be used to determine the content of impurities in oxide crystals [30] with sufficiently low LoDs. However, this technique has high instrumental and operational costs, which limits its routine application.

The aim of the current study was to develop a direct and sensitive method capable of the quantification of matrix and admixture elements in optical crystals, using $\mathrm{KGd}_{1-\mathrm{y}} \mathrm{Nd}_{\mathrm{y}}\left(\mathrm{WO}_{4}\right)_{2}$ and $\mathrm{K}_{1-\mathrm{x}} \mathrm{Rb}_{\mathrm{x}} \mathrm{TiOPO}_{4}$ as examples.

\section{Materials and Methods}

\subsection{Instrumentation}

The stoichiometry monitoring was developed based on microsecond pulsed glow discharge time-of-flight mass spectrometry ( $\mu$ s-PDC TOF GDMS) using a time-of-flight mass spectrometer Lumas-30 (Lumex, St. Petersburg, Russia) with a pulsed direct current glow discharge (DC GD) ionization source. The construction and technical characteristics of the instrument were described previously [26,31]. Special features of ionization processes and ion extraction in the $\mu s-P D C$ TOF GDMS system are described in ref. [32]. In brief, the sample is gradually sputtered and ionized by argon plasma, and the ion components are detected by the time-of-flight mass spectrometer. A repelling pulse following the sputtering/ionizing discharge pulse channels the ions into the mass analyzer; the repelling pulse is synchronized with the discharge pulse and initiates after a delay-a repelling pulse delay. The combined hollow cathode ( $\mathrm{CHC}$ ) was used in this study. The discharge cell consisted of a hollow metallic cylinder (auxiliary cathode) with a diameter of $6 \mathrm{~mm}$ and the sample under study attached to it. In the current study, auxiliary cathodes made of high purity tantalum $(99.99 \%)$ and 
aluminum (99.999\%) were considered. A mixture of high purity argon $(99.9999 \%)$ with $0.3 \%$ addition of hydrogen (LindeGaz Rus, St. Petersburg, Russia) was used as the discharge gas. Quantification data were calculated from six replicate measurements $(n=6)$ and are presented as mean \pm confidence interval $(n=6, P=0.95)$

\subsection{Samples}

The crystals under study were grown at the Research and Technological Institute of Optical Materials All-Russia Scientific Center "S.I. Vavilov State Optical Institute", using the TSSG method. In total, three crystals were tested: $\mathrm{K}_{1-\mathrm{x}} \mathrm{Rb}_{\mathrm{x}} \mathrm{TiOPO}_{4}$ with $\mathrm{x}=0.002$ and 0.05 , and $\mathrm{KGd}_{1-\mathrm{y}} \mathrm{Nd}_{\mathrm{y}}\left(\mathrm{WO}_{4}\right)_{2}$ with $y=0.05$ in the growth charge.

The $\mathrm{K}_{1-\mathrm{x}} \mathrm{Rb}_{\mathrm{x}} \mathrm{TiOPO}_{4}$ crystals were grown from a phosphate melt solution. The procedure applied was as follows: the chemicals of $99.9 \%$ purity $\mathrm{K}_{2} \mathrm{CO}_{3}, \mathrm{Rb}_{2} \mathrm{CO}_{3}, \mathrm{KH}_{2} \mathrm{PO}_{4}$, and $\mathrm{TiO}_{2}$ ( $\geq 99 \%$; Sigma Aldrich, Merck KGaA, Darmstadt, Germany) were loaded into a platinum crucible and fused at $980{ }^{\circ} \mathrm{C}$. During the crystal growth, the temperature of the melt solution decreased about $50-70{ }^{\circ} \mathrm{C}$, whilst the growth rate was maintained at ca. $0-3 \mathrm{~mm} /$ day.

To grow $\mathrm{KGd}_{1-\mathrm{y}} \mathrm{Nd}_{\mathrm{y}}\left(\mathrm{WO}_{4}\right)_{2}$ crystals, the growth charge was prepared by mixing $\mathrm{Gd}_{2} \mathrm{O}_{3}, \mathrm{Nd}_{2} \mathrm{O}_{3}$, $\mathrm{WO}_{3}$, and $\mathrm{K}_{2} \mathrm{CO}_{3}(\geq 99 \%$, Sigma-Aldrich, Merck KGaA, Darmstadt, Germany) in the required proportions in a platinum crucible followed by consequent calcination. The equilibrium temperature (980-1020 ${ }^{\circ} \mathrm{C}$ ) was achieved under constant stirring in $40 \%$ melt solution of $\mathrm{KGd}(\mathrm{Nd})\left(\mathrm{WO}_{4}\right)_{2}$ and $\mathrm{K}_{2} \mathrm{~W}_{2} \mathrm{O}_{7}$. The temperature decrease rate was 1 to $5{ }^{\circ} \mathrm{C}$ per day. The total growth procedure took up to one month.

\subsection{Sample Preparation}

The parts of the crystals proximal to the initial crystal seeding are further referred to as the "top"; the opposite part of the crystal is referred to as the "bottom". To study the elemental composition in the crystal faces and along different crystallographic axes, corresponding plates of $2 \mathrm{~mm}$ thickness were cut. $\mathrm{K}_{0.998} \mathrm{Rb}_{0.002} \mathrm{TiOPO}_{4}$ cutting is shown in Figure 1a. Diffraction shadow images of the samples, obtained using a DRSh-250 setup equipped with a mercury-arc lamp (S.I. Vavilov State Optical Institute, Saint-Petersburg, Russia), are presented in Figure $1 b, c$. The crystal was investigated along the growth axis on the plate N0 (shadow image is shown in Figure 1b) and on the growth sector of crystal faces (Figure 1c). For the $\mathrm{K}_{0.95} \mathrm{Rb}_{0.05} \mathrm{TiOPO}_{4}$ crystal, growth faces (201) and (100) along the growth axis as well as the fragments from the top and bottom were investigated. The plate of $\mathrm{KGd}_{1-\mathrm{y}} \mathrm{Nd}_{\mathrm{y}}\left(\mathrm{WO}_{4}\right)_{2}$ crystal was cut along the growth axis; additionally, the plates perpendicular to the growth axis were cut from the top and the bottom parts. The samples were polished with diamond pastes of different grain sizes. For the $\mu \mathrm{s}-\mathrm{PDC}$ TOF GDMS analysis, the sections of 10-20 mm were used.

\subsection{Calibration}

A panel of powdered calibration specimens with the close matrix to the samples under study was used. For $\mathrm{K}_{1-\mathrm{x}} \mathrm{Rb}_{\mathrm{x}} \mathrm{TiOPO}_{4}$, calibration specimens were prepared by mixing $\mathrm{K}_{2} \mathrm{CO}_{3}, \mathrm{Rb}_{2} \mathrm{CO}_{3}, \mathrm{KH}_{2} \mathrm{PO}_{4}$, and $\mathrm{TiO}_{2}\left(\geq 99 \%\right.$, Sigma-Aldrich, Merck KGaA, Darmstadt, Germany) with consequent fusion at $660^{\circ} \mathrm{C}$ for $24 \mathrm{~h}$. The polycrystalline charges with the matching matrix to $\mathrm{K}_{1-\mathrm{x}} \mathrm{Rb}_{\mathrm{x}} \mathrm{TiOPO}_{4}$ were obtained $(x$ in the range of 0.025-0.25). The composition of the calibration specimens is presented in Supplementary Table S1.

In the case of $\mathrm{KGd}_{1-\mathrm{y}} \mathrm{Nd}_{\mathrm{y}}\left(\mathrm{WO}_{4}\right)_{2}$, to calibrate for $\mathrm{Nd}$ (range $0.1-3$ at $\%$ in the powder) and $\mathrm{Gd}$ (4-14 at $\%$ in the powder) the following chemicals were used: $\mathrm{KCl}(99.5 \%), \mathrm{WO}_{3}(99.5 \%), \mathrm{Al}$ powder $(99.9 \%), \mathrm{Nd}_{2} \mathrm{O}_{3}(99.9 \%)$, all purchased from Merck KGaA, Darmstadt, Germany. All required materials were thoroughly ground in an agate mortar for at least $30 \mathrm{~min}$ and then pressed into tablets (diameter $10 \mathrm{~mm}$, thickness $2 \mathrm{~mm}$ ) with the use of a manual hydraulic press PRG-400 (Rost, Moscow, Russia). The level of grinding and homogenization was controlled using a scanning electron microscope Zeiss 
Merlin (Carl Zeiss AG, Oberkochen, Germany). The composition of the calibration specimens is presented in Supplementary Table S2.

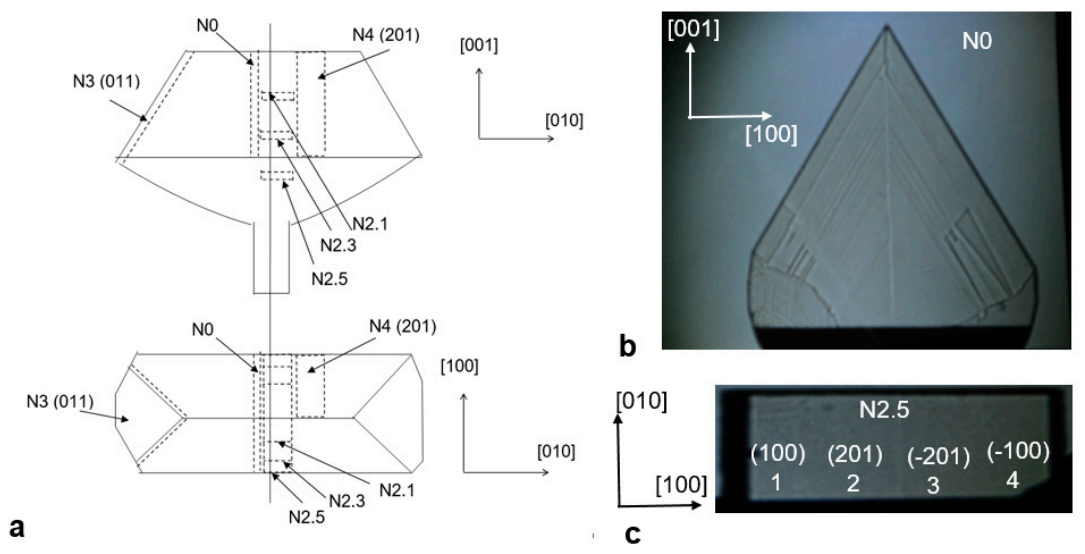

Figure 1. Scheme of the $\mathrm{K}_{0.998} \mathrm{Rb}_{0.002} \mathrm{TiOPO}_{4}$ crystal (a) and diffraction shadow images of samples N0 (b) and N2.5 (c) indicating growth sectors of different faces. Sample N0 was used for measurements of $\mathrm{Rb}$ distribution along the growth axis [001].

\subsection{Characterisation by Other Techniques and Reference Material Analysis}

The quantification of trivalent $\mathrm{Nd}$ in $\mathrm{KGd}_{1-\mathrm{y}} \mathrm{Nd}_{\mathrm{y}}\left(\mathrm{WO}_{4}\right)_{2}$ was performed using a spectrophotometer UV-3600 (Shimadzu Europa GmbH, Duisburg, Germany). A wavelength of $584 \mathrm{~nm}$ was used for the measurement. Spectrophotometry data were calculated from six replicate measurements $(n=6)$ and are presented as mean \pm confidence interval $(n=6, P=0.95)$.

For the colorless $\mathrm{K}_{1-\mathrm{x}} \mathrm{Rb}_{\mathrm{x}} \mathrm{TiOPO}_{4}$ crystal elemental characterization, a scanning electronic microscope Hitachi S-3400N (Hitachi, Tokyo, Japan), equipped with energy dispersive spectrometer X-Max 20 from Oxford Instruments (Abingdon, UK) with a Si detector was used. The spectrum was acquired for $30 \mathrm{~s}$ under an accelerating voltage of $20 \mathrm{kV}$ and probe current of $1.8 \mathrm{nA}$. The beam current was optimized using metallic titanium every $30 \mathrm{~min}$. The MAC (Micro-Analysis Consultants Ltd.) reference materials were used for standardization: Nd REE Glass and Gd REE glass for Nd and Gd, respectively; potassium chloride (99.9\%) for K; and anhydrous rubidium nitrate (99.99\%), purchased from Novosibirsk Rare Metals Plant Russia, for Rb. For the calibration, a spectrum of the standard was acquired for $120 \mathrm{~s}$ in the same conditions $(20 \mathrm{kV}, 1.8 \mathrm{nA})$. Matrix effects were automatically corrected via TrueQ procedure (based on the XPP algorithm) using Oxford Aztec Energy software. The estimation of the limit of quantification (LoQ) was performed based on the measurement of pure (non-doped) KTP crystal. The LoQ value was calculated as the 10 -fold value of the standard deviation obtained for 10 replicate measurements $(n=10)$. SEM-EDX quantification data were calculated from 10 replicate measurements $(n=10)$ and are presented as mean \pm confidence interval $(n=10, P=0.95)$

To validate the $\mu$ s-PDC TOF GDMS method, in respect of the determination of $\mathrm{Rb} / \mathrm{K} w \mathrm{t} \%$ ratio, a geological state certified reference material SGD-1A Essexitic Gabbro (A.P. Vinogradov Institute of Geochemistry SB RAS, Irkutsk, Russia) was used. This reference material contains $\mathrm{Rb}=0.0073 \pm 0.0004 \mathrm{wt} \%, \mathrm{~K}=2.46 \pm 0.04 \mathrm{wt} \%$, and $\mathrm{Ti}=1.03 \pm 0.02 \mathrm{wt} \%$.

\subsection{Electrictrical Conductivity Measurements}

The conductivity of the crystals was studied by electrochemical impedance spectroscopy over $1 \mathrm{MHz}$ to $0.01 \mathrm{~Hz}$ frequency range. For this purpose, an Autolab PGSTAT302 potentiostat/galvanostat (Metrohm AG, Herisau, Switzerland) with a quartz cell maintained in nitrogen atmosphere was used (procedure as described in ref. [33]). 


\section{Results and Discussion}

\subsection{Method Development}

Direct sputtering of $\mathrm{K}_{1-\mathrm{x}} \mathrm{Rb}_{\mathrm{x}} \mathrm{TiOPO}_{4}$ and $\mathrm{KGd}_{1-\mathrm{y}} \mathrm{Nd}_{\mathrm{y}}\left(\mathrm{WO}_{4}\right)_{2}$ crystals resulted in extremely low intensities in the mass spectrum. Thus, the previously employed approach with silver surface coating was used [34]. For $\mathrm{K}_{1-\mathrm{x}} \mathrm{Rb}_{\mathrm{x}} \mathrm{TiOPO}_{4}$, effective sample sputtering was ensured with silver coating after 10-15 min from the initiation of the discharge. An example of a mass spectrum is shown in Figure 2a. However, for $\mathrm{KGd}_{1-\mathrm{y}} \mathrm{Nd}_{\mathrm{y}}\left(\mathrm{WO}_{4}\right)_{2}$, the silver coating was found to be ineffective, since a low sputtering rate of the bulk of the crystal was still observed. Consequently, an alternative sample preparation protocol was implemented. A small piece of a $\mathrm{KGd}_{1-\mathrm{y}} \mathrm{Nd}_{\mathrm{y}}\left(\mathrm{WO}_{4}\right)_{2}$ crystal (20-30 mg) was pressed into high purity aluminum to form a tablet ( $2 \mathrm{~mm}$ thick, $10 \mathrm{~mm}$ diameter). An aluminum auxiliary cathode was used in order to minimize the number of additional components in the mass spectrum. This protocol ensured effective sputtering of $\mathrm{KGd}_{1-\mathrm{y}} \mathrm{Nd}_{\mathrm{y}}\left(\mathrm{WO}_{4}\right)_{2}$ with increased sensitivity of ca. 2 orders of magnitude compared with unprepared crystal. Figure $2 \mathrm{~b}$ demonstrates a sample mass spectrum of $\mathrm{KGd}_{1-\mathrm{y}} \mathrm{Nd}_{\mathrm{y}}\left(\mathrm{WO}_{4}\right)_{2}$.
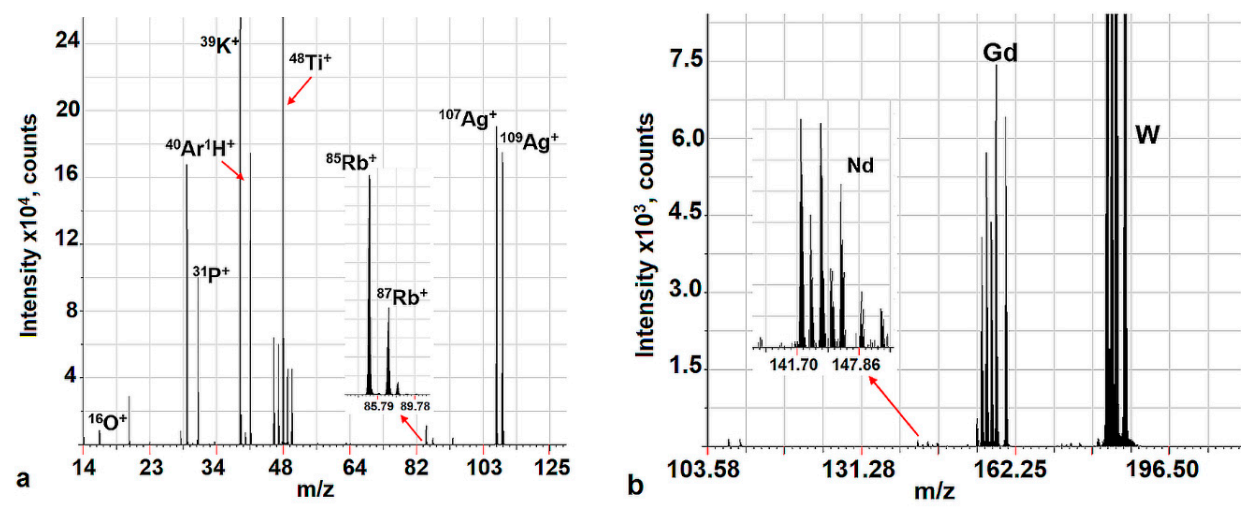

Figure 2. A mass spectrum range of $\mathrm{K}_{0.95} \mathrm{Rb}_{0.05} \mathrm{TiOPO}_{4}(\mathbf{a})$ and $\mathrm{KGd}_{0.95} \mathrm{Nd}_{0.05}\left(\mathrm{WO}_{4}\right)_{2}$ (b) crystals. Both mass spectra were acquired using optimal parameters.

The next stage of the study involved the optimization of the discharge parameters, analogously to our previous publications [26,35]. The optimal parameters for $\mathrm{K}_{1-\mathrm{x}} \mathrm{Rb}_{\mathrm{x}} \mathrm{TiOPO}_{4}$ crystals were as follows: repelling pulse delay $4 \mu \mathrm{s}$, discharge duration $3 \mu \mathrm{s}$, discharge voltage $1300 \mathrm{~V}$, and cell pressure $37 \mathrm{~Pa}$. For $\mathrm{KGd}_{1-\mathrm{y}} \mathrm{Nd}_{\mathrm{y}}\left(\mathrm{WO}_{4}\right)_{2}$ specimens, the parameters were as follows: repelling pulse delay $200 \mu \mathrm{s}$, discharge duration $4 \mu \mathrm{s}$, discharge voltage $1300 \mathrm{~V}$, and cell pressure $40 \mathrm{~Pa}$.

The following linear calibration curves for $\mathrm{K}, \mathrm{Rb}, \mathrm{Nd}$, and $\mathrm{Gd}$ were obtained (Figure 3). 
K

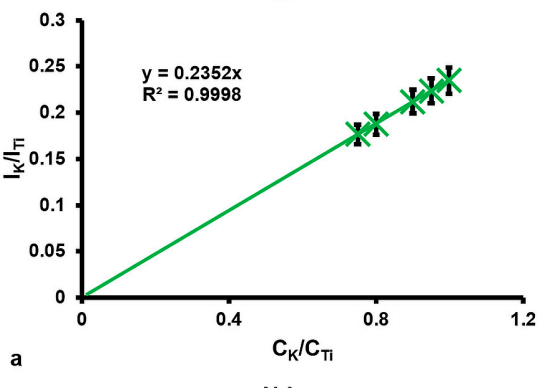

Nd

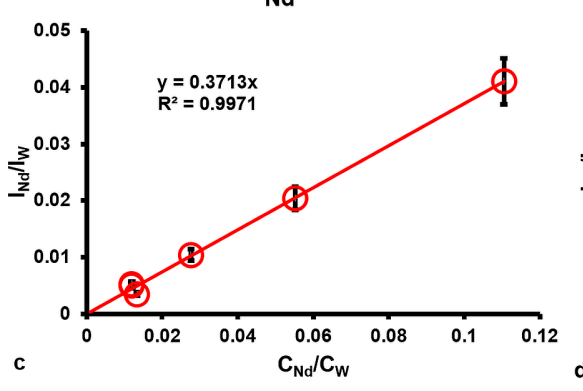

Rb

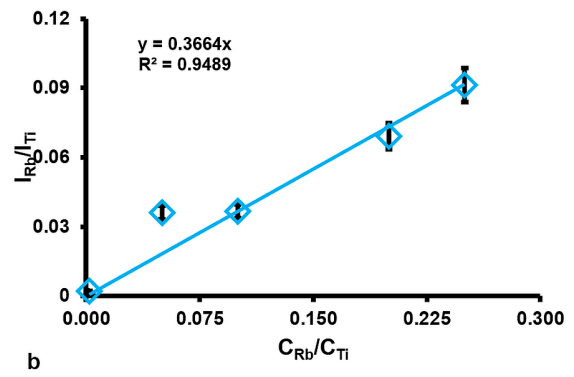

Gd

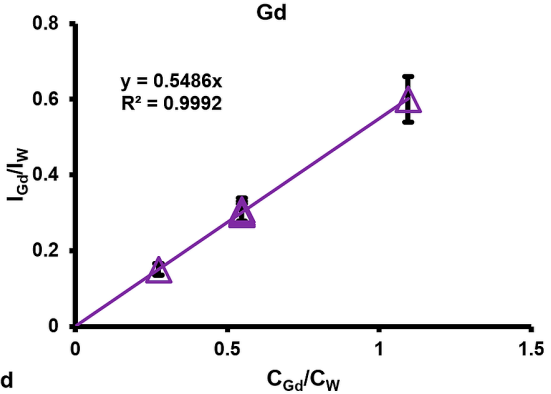

Figure 3. Calibration curves for $\mathrm{K}(\mathbf{a}), \mathrm{Rb}(\mathbf{b}), \mathrm{Nd}(\mathbf{c})$, and $\mathrm{Gd}(\mathbf{d}) ; \mathrm{K}$ and $\mathrm{Rb}$ were calibrated using the specimens presented in supplementary Table S1. Nd and Gd were calibrated using the specimens presented in supplementary Table S2 (K: $0.235 x, R^{2}=0.9998 ; R b: 0.366 x, R^{2}=0.9489$; Nd: 0.371x, $\left.\mathrm{R}^{2}=0.9971 ; \mathrm{Gd}: 0.549 \mathrm{x}, \mathrm{R}^{2}=0.9992\right)$.

\section{2. $\mathrm{KGd}_{0.95} \mathrm{Nd}_{0.05}\left(\mathrm{WO}_{4}\right)_{2}$ Crystals}

We studied the distributions of $\mathrm{Nd}$ and Gd along the crystals' growth axis using $\mu$ s-PDC TOF GDMS (Table 1). The concentrations at the top and bottom of the crystals were validated using a standard spectrophotometric assay, routinely used for the quality assurance of these crystals by the manufacturer. Importantly, both techniques provided an acceptable agreement within the experimental uncertainty. SEM EDX could not be used for validation due to the low levels of $\mathrm{Nd}$ in the specimens. As can be seen from Table 1, there was an increase in Nd concentration in the crystal in the growth process.

Table 1. Atomic fraction ratios of Nd/Gd along the crystallographic growth axis from the crystal's top (seeding side-1) to its bottom (opposite side-5).

\begin{tabular}{|c|c|c|}
\hline \multirow[b]{2}{*}{ Section of Crystal } & \multicolumn{2}{|c|}{ Nd/Gd Atomic Fraction Ratio } \\
\hline & $\begin{array}{l}\text { Spectrophotometry } \\
\quad(n=6, P=0.95)\end{array}$ & $\begin{array}{l}\mu s-P D C \text { TOF GDMS } \\
(n=6, P=0.95)\end{array}$ \\
\hline 1 (top) & $0.035 \pm 0.003$ & $0.035 \pm 0.002$ \\
\hline 2 & $\mathrm{~N} / \mathrm{A}$ & $0.039 \pm 0.002$ \\
\hline 3 & $\mathrm{~N} / \mathrm{A}$ & $0.040 \pm 0.002$ \\
\hline 4 & $\mathrm{~N} / \mathrm{A}$ & $0.043 \pm 0.002$ \\
\hline 5 (bottom) & $0.045 \pm 0.004$ & $0.046 \pm 0.002$ \\
\hline
\end{tabular}

According to the literature, the distribution coefficients depend on the concentration of the doping component, unstable within the bulk of the crystal, and usually vary in the range from 0.6 to $1[2,11,36]$. In our case, the distribution coefficient was found to be 0.67 at the top and 0.93 at the bottom of the crystal. This demonstrates the necessity to monitor the dopant after the crystal growth to ensure the quality. 


\section{3. $\mathrm{K}_{1-x} \mathrm{R} b_{x} \mathrm{TiOPO}_{4}$ Crystals}

The plates of $\mathrm{K}_{1-\mathrm{x}} \mathrm{Rb}_{\mathrm{x}} \mathrm{TiOPO}_{4}(\mathrm{x}=0.002$ and 0.05$)$ crystals were studied. SEM EDX was used for data comparison. The limits of quantification (LoQ) of SEM EDX were insufficient to quantify $\mathrm{Rb}$ in the $\mathrm{K}_{0.998} \mathrm{Rb}_{0.002} \mathrm{TiOPO}_{4}$ crystal but were applicable for the $\mathrm{Rb}$-enriched $\mathrm{K}_{0.95} \mathrm{Rb}_{0.05} \mathrm{TiOPO}_{4}$ sample. For the latter, the results of $\mu$ s-PDC TOF GDMS and SEM EDX were in adequate agreement, given the uncertainty of the measurements. The data on the inhomogeneous distribution of the dopant $(\mathrm{Rb})$ was also corroborated by the resistance measurements (Table 2), which also demonstrated variability along the growth axis. The inhomogeneity of the chemical composition was observed both along the growth axis and for different growth sectors of crystal faces. We tested the distribution of the dopant along different crystallographic axes, observing much higher homogeneity compared with the growth axis. The average distribution coefficients were found to be 0.70 and 0.63 for $\mathrm{K}_{0.998} \mathrm{Rb}_{0.002} \mathrm{TiOPO}_{4}$ and $\mathrm{K}_{0.95} \mathrm{Rb}_{0.05} \mathrm{TiOPO}_{4}$, respectively. The inhomogeneity observed is related to the gradual decrease of the temperature and the enrichment of the melt solution with the dopant during the growth process.

Table 2. Atomic fraction ratios of $\mathrm{Rb} / \mathrm{K}$ in $\mathrm{K}_{1-\mathrm{x}} \mathrm{Rb}_{\mathrm{x}} \mathrm{TiOPO}_{4}$ crystals ( $\mathrm{x}=0.002$ and 0.05 ), determined by scanning electron microscope-energy dispersive X-ray spectroscopy (SEM EDX) and microsecond direct current pulsed glow discharge time-of-flight mass spectrometry ( $\mu$ s-PDC TOF GDMS) along the crystallographic growth axis from the crystal's top (seeding side-1) to its bottom (opposite side -5 and 3 for $\mathrm{K}_{0.998} \mathrm{Rb}_{0.002} \mathrm{TiOPO}_{4}$ and $\mathrm{K}_{0.95} \mathrm{Rb}_{0.05} \mathrm{TiOPO}_{4}$, respectively). Sample $\mathrm{N} 0$ was used for measurements of $\mathrm{Rb}$ distribution along the growth axis [001] for the $\mathrm{K}_{0.998} \mathrm{Rb}_{0.002} \mathrm{TiOPO}_{4}$ crystal.

\begin{tabular}{|c|c|c|c|c|c|}
\hline \multirow[b]{2}{*}{ Crystal Formula } & \multirow{2}{*}{$\begin{array}{l}\text { Section of } \\
\text { the Crystal }\end{array}$} & \multicolumn{3}{|c|}{$\mathrm{Rb} / \mathrm{K}$ Atomic Fraction Ratio } & \multirow{2}{*}{$\begin{array}{c}\mathrm{R} \times 10^{5}, \\
\mathrm{Ohm} / \mathrm{cm} \\
\mathrm{T}=105^{\circ} \mathrm{C}\end{array}$} \\
\hline & & In the Charge & $\begin{array}{c}\mu s-P D C \text { TOF GDMS } \\
(\mathrm{n}=6, \mathrm{P}=0.95)\end{array}$ & $\begin{array}{c}\text { SEM EDX } \\
(\mathrm{n}=10, \mathrm{P}=0.95)\end{array}$ & \\
\hline \multirow{5}{*}{$\mathrm{K}_{0.998} \mathrm{Rb}_{0.002} \mathrm{TiOPO}_{4}$} & 1 (top) & \multirow{5}{*}{$2.00 \cdot 10^{-3}$} & $(9.1 \pm 0.5) \cdot 10^{-4}$ & \multirow{5}{*}{$<$ LoQ } & $11.4 \pm 0.6$ \\
\hline & 2 & & $(1.00 \pm 0.07) \cdot 10^{-3}$ & & $11.3 \pm 0.5$ \\
\hline & 3 & & $(1.04 \pm 0.06) \cdot 10^{-3}$ & & $19.2 \pm 0.9$ \\
\hline & 4 & & $(1.96 \pm 0.12) \cdot 10^{-3}$ & & $22.1 \pm 1.1$ \\
\hline & 5 (bottom) & & $(2.33 \pm 0.14) \cdot 10^{-3}$ & & $25.8 \pm 1.3$ \\
\hline \multirow{3}{*}{$\mathrm{K}_{0.95} \mathrm{Rb}_{0.05} \mathrm{TiOPO}_{4}$} & 1 (top) & \multirow{3}{*}{$5.3 \cdot 10^{-2}$} & $(3.5 \pm 0.2) \cdot 10^{-2}$ & $(3.6 \pm 0.3) \cdot 10^{-2}$ & \multirow{3}{*}{ N/A } \\
\hline & 2 & & $(3.7 \pm 0.2) \cdot 10^{-2}$ & $(3.6 \pm 0.4) \cdot 10^{-2}$ & \\
\hline & 3 (bottom) & & $(3.8 \pm 0.2) \cdot 10^{-2}$ & $(3.7 \pm 0.4) \cdot 10^{-2}$ & \\
\hline
\end{tabular}

N/A—not analyzed; $<$ LoQ— below the limit of quantification (ca. 0.025).

For further study of the dopant's distribution in the $\mathrm{K}_{0.998} \mathrm{Rb}_{0.002} \mathrm{TiOPO}_{4}$ crystal, the following crystal plates (Figure 1) were investigated at points 1 and 4, faces (100) and (-100); and points 2 and 3, faces (201) and (-201). For $\mathrm{K}_{0.95} \mathrm{Rb}_{0.05} \mathrm{TiOPO}_{4}$ we additionally studied crystal faces (201) and (100). SEM EDX was again used for data comparison. In these plates, the material was supposed to be growing simultaneously, so the dopant's concentration may be evaluated in two growth sectors. Considerable differences in elemental composition (Table 3) were observed for faces $\{201\}$ and $\{100\}$ for $\mathrm{K}_{0.998} \mathrm{Rb}_{0.002} \mathrm{TiOPO}_{4}$ and $\mathrm{K}_{0.95} \mathrm{Rb}_{0.05} \mathrm{TiOPO}_{4}$. The growth centers on the face (100) are known to be related to the dislocations originating for the seeding's regeneration or under defect growth of faces $\{110\}$ and $\{011\}$ [37]. On the face $\{201\}$, there are nearly no such dislocation centers; the face $\{201\}$ was previously shown to grow through the edge mechanism [37].

For the validation of the method, geological state reference material SGD-1A Essexitic Gabbro (A.P. Vinogradov Institute of Geochemistry SB RAS, Irkutsk, Russia) containing Rb $=0.0073 \pm 0.0004 \mathrm{wt} \%$ and $\mathrm{K}=2.46 \pm 0.04 \mathrm{wt} . \%$ was analyzed. The following concentrations were obtained using the developed method: $0.0076 \pm 0.0009$ and $2.43 \pm 0.15 \mathrm{wt} . \%(\mathrm{n}=6, \mathrm{P}=0.95)$ for $\mathrm{Rb}$ and $\mathrm{K}$, respectively. Like for the real KTP samples, titanium was used for normalization (Ti content in SGD-1A is $1.03 \pm 0.02 \mathrm{wt} \%$ ). The comparison with the certified value demonstrated reliable agreement $(\alpha<0.05)$. 
Table 3. Atomic fraction ratios of $\mathrm{Rb} / \mathrm{K}$ in $\mathrm{K}_{1-\mathrm{x}} \mathrm{Rb}_{\mathrm{x}} \mathrm{TiOPO}_{4}$ crystals ( $\mathrm{x}=0.002$ and 0.05 ), determined by scanning electron microscope-energy dispersive $X$-ray spectroscopy (SEM EDX) and microsecond direct current pulsed glow discharge time-of-flight mass spectrometry ( $\mu$ s-PDC TOF GDMS) in different sector growth faces. For details on crystal cutting, please refer to Figure 1.

\begin{tabular}{|c|c|c|c|c|}
\hline \multirow[b]{2}{*}{ Crystal formula } & \multirow[b]{2}{*}{ Growth Sector } & \multicolumn{3}{|c|}{$\mathrm{Rb} / \mathrm{K}$ Atomic Fraction Ratio } \\
\hline & & In the Charge & $\begin{array}{c}\mu s-P D C \text { TOF GDMS } \\
(n=6, P=0.95)\end{array}$ & $\begin{array}{c}\text { SEM EDX } \\
(\mathrm{n}=10, \mathrm{P}=0.95)\end{array}$ \\
\hline \multirow{4}{*}{$\mathrm{K}_{0.998} \mathrm{Rb}_{0.002} \mathrm{TiOPO}_{4}$} & $(100)-1$ & \multirow{4}{*}{$2.00 \times 10^{-3}$} & $(7.3 \pm 0.4) \times 10^{-4}$ & \multirow{4}{*}{$<$ LoQ } \\
\hline & $(201)-2$ & & $(1.5 \pm 0.1) \times 10^{-3}$ & \\
\hline & $(-201)-3$ & & $(1.9 \pm 0.1) \times 10^{-3}$ & \\
\hline & $(-100)-4$ & & $(1.31 \pm 0.1) \times 10^{-3}$ & \\
\hline \multirow{2}{*}{$\mathrm{K}_{0.95} \mathrm{Rb}_{0.05} \mathrm{TiOPO}_{4}$} & $(100)$ & \multirow{2}{*}{$5.3 \times 10^{-2}$} & $(3.1 \pm 0.2) \times 10^{-2}$ & $(3.0 \pm 0.4) \times 10^{-2}$ \\
\hline & (201) & & $(2.5 \pm 0.1) \times 10^{-2}$ & $(2.4 \pm 0.3) \times 10^{-2}$ \\
\hline
\end{tabular}

\section{Conclusions}

In the current study, a direct method of dopant distribution analysis in optical single crystals was developed based on time-of-flight mass spectrometry with pulsed glow discharge. The applicability of the method was demonstrated while determining matrix and dopant components in two types of optical crystals, $\mathrm{K}_{1-\mathrm{x}} \mathrm{Rb}_{\mathrm{x}} \mathrm{TiOPO}_{4}$ and $\mathrm{KGd}_{1-\mathrm{y}} \mathrm{Nd}_{\mathrm{y}}\left(\mathrm{WO}_{4}\right)_{2}$. For $\mathrm{KGd}_{0.95} \mathrm{Nd}_{0.05}\left(\mathrm{WO}_{4}\right)_{2}$, we were able to validate the method using spectrophotometry based on $\mathrm{Nd}^{3+}$ absorption. For non-absorbing $\mathrm{K}_{1-\mathrm{x}} \mathrm{Rb}_{\mathrm{x}} \mathrm{TiOPO}_{4}$, we could not validate the low concentration level due to insufficient sensitivity of the reference technique, since the designed method showed higher sensitivity than the reference techniques; however, the higher concentration range was compared and showed good agreement between the techniques. For both crystal types, considerable inhomogeneity in the dopant's distribution was observed along the growth axis, whereas for $\mathrm{K}_{1-\mathrm{x}} \mathrm{Rb}_{\mathrm{x}} \mathrm{TiOPO}_{4}$, the difference was observed also in the growth sectors. Thus, $\mu$ s-PDC TOF GDMS was demonstrated to be an effective and sensitive tool for the monitoring of the composition of optical single crystals.

Supplementary Materials: The following are available online at http://www.mdpi.com/2073-4352/10/6/458/s1, Table S1: Composition of the specimens used for calibrating of $\mu$ s-PDC TOF GDMS system for analysis of $\mathrm{K}_{1-\mathrm{x}} \mathrm{Rb}_{\mathrm{x}} \mathrm{TiOPO}_{4}$ crystals. The preparation of the specimens is described in the main text in brief; Table S2: Composition of the specimens used for calibrating of $\mu \mathrm{s}-\mathrm{PDC}$ TOF GDMS system for analysis of $\mathrm{KGd}_{1-\mathrm{y}} \mathrm{Nd}_{\mathrm{y}}\left(\mathrm{WO}_{4}\right)_{2}$ crystals. The preparation of the specimens is described in the main text in brief.

Author Contributions: Conceptualization, A.G. (Anna Gubal) and V.C.; methodology, V.C. and A.G. (Alexander Ganeev); software, O.G. and N.S.; validation, A.G. (Anna Gubal), V.C., I.T., and A.G. (Alexander Ganeev); formal analysis, A.T. and V.Y.; investigation, A.G. (Anna Gubal), V.C., O.G., and A.G. (Alexander Ganeev); resources, A.T. and V.Y.; data curation, A.G. (Anna Gubal); writing-original draft preparation, A.G. (Anna Gubal), V.C., and N.S.; writing-review and editing, A.G. (Anna Gubal), V.C., N.S., and A.G. (Alexander Ganeev); visualization, V.C.; supervision, A.G. (Anna Gubal) and A.G. (Alexander Ganeev); project administration, N.S.; funding acquisition, A.G. (Anna Gubal). All authors have read and agree to the published version of the manuscript.

Funding: The research was funded by the Russian Science Foundation (Grant No. 17-73-20089).

Acknowledgments: The authors are grateful to the St. Petersburg State University Research Park (St. Petersburg State University, St. Petersburg, Russia): Interdisciplinary Resource Centers for Nanotechnology, Chemical Analysis and Materials and "Geomodel", for providing access to their facilities.

Conflicts of Interest: The authors declare no conflict of interest. The funders had no role in the design of the study; in the collection, analyses, or interpretation of data; in the writing of the manuscript; or in the decision to publish the results. 


\section{References}

1. Luo, X.; Li, Z.; Guo, Y.; Yao, J.; Wu, Y. Recent progress on new infrared nonlinear optical materials with application prospect. J. Solid State Chem. 2019, 270, 674-687. [CrossRef]

2. Solé, R.; Nikolov, V.; Ruiz, X.; Gavaldà, J.; Solans, X.; Aguiló, M.; Díaz, F. Growth of $\beta-\mathrm{KGd}_{1-\mathrm{x}} \mathrm{Nd}_{\mathrm{x}}\left(\mathrm{WO}_{4}\right)_{2}$ single crystals in $\mathrm{K}_{2} \mathrm{~W}_{2} \mathrm{O}_{7}$ solvents. J. Cryst. Growth 1996, 169, 600-603. [CrossRef]

3. Han, J.; Guo, H.; Zhang, M.; Song, N.; Xu, C. Characterization of large-sized Nd:YAG single crystals grown by horizontal directional solidification. Cryst. Res. Technol. 2012, 47, 485-490. [CrossRef]

4. Zhang, M.; Guo, H.; Han, J.; Zhang, H.; Xu, C. Distribution of Neodymium and properties of Nd:YAG crystal by horizontal directional solidification. J. Cryst. Growth 2012, 340, 130-134. [CrossRef]

5. Kumaran, A.; Chandru, A.; Moorthy Babu, S.; Bhaumik, I.; Ganesamoorthy, S.; Karnal, A.K.; Wadhawan, V.; Ichimura, M. Crystal growth of pure and doped-KGd($\left(\mathrm{WO}_{4}\right)_{2}$ and their characterization for laser applications. J. Cryst. Growth 2005, 275, e2117-e2121. [CrossRef]

6. Michalski, E.; Zmija, J.; Mierczyk, Z.; Majchrowski, A.; Kopczynski, K.; Cichowski, S.; Wojtanowski, J. Optical properties of doped potassium gadolinium tungstate single crystals. In Proceedings of the International Conference on Solid State Crystals 2000: Growth, Characterization, and Applications of Single Crystals, Zakopane, Poland, 10 August 2001. [CrossRef]

7. Guretskii, S.A.; Luginets, A.M.; Kolesova, I.M.; Kravtsov, A.V.; Malyutin, V.B.; Ermolaev, A.A.; Karpenko, S.A. Features of the $\mathrm{KGd}\left(\mathrm{WO}_{4}\right)_{2}: \mathrm{Nd}^{3+}$ single-crystal growth control. J. Cryst. Growth 2009, 311, 1529-1532. [CrossRef]

8. Tseitlin, M.; Mojaev, E.; Roth, M. Growth of high resistivity RbTiOPO 4 crystals. J. Cryst. Growth 2008, 310, 1929-1933. [CrossRef]

9. Roth, M.; Tseitlin, M.; Angert, N. Composition-dependent electro-optic and nonlinear optical properties of KTP-family crystals. Opt. Mater. 2006, 28, 71-76. [CrossRef]

10. Kushawaha, V.; Michael, A.; Major, L. Effect of Nd concentration on the Nd:KGW laser. Appl. Phys. B 1994, 58, 533-535. [CrossRef]

11. Pujol, M.C.; Solé, R.; Gavaldà, J.; Massons, J.; Aguiló, M.; Díaz, F.; Nikolov, V.; Zaldo, C. Growth and ultraviolet optical properties of $\mathrm{KGd}_{1-\mathrm{x}} \mathrm{RE}_{\mathrm{x}}\left(\mathrm{WO}_{4}\right)_{2}$ single crystals. J. Mater. Res. 1999, 14, 3739-3745. [CrossRef]

12. Antsygin, V.D.; Mamrashev, A.A.; Nikolaev, N.A. Optical properties of Nd:KGW crystal in the range of 0.2-2.1 THz. Results Phys. 2020, 16, 102842. [CrossRef]

13. Senthil Kumaran, A.; Moorthy Babu, S.; Ganesamoorthy, S.; Bhaumik, I.; Karnal, A.K. Crystal growth and characterization of $\mathrm{KY}\left(\mathrm{WO}_{4}\right)_{2}$ and $\mathrm{KGd}\left(\mathrm{WO}_{4}\right)_{2}$ for laser applications. J. Cryst. Growth 2006, 292, 368-372. [CrossRef]

14. Tu, C.; Luo, Z.; Chen, G.; Zhao, T. Crystal growth of $\mathrm{KGd}\left(\mathrm{WO}_{4}\right)_{2}: \mathrm{Nd}^{3+}$. J. Cryst. Growth 1995, 152, $235-237$. [CrossRef]

15. Azrakantsyan, M.; Albach, D.; Ananyan, N.; Gevorgyan, V.; Chanteloup, J.C. Yb ${ }^{3+}$ : YAG crystal growth with controlled doping distribution. Opt. Mater. Express 2012, 2, 20-30. [CrossRef]

16. Shaldin, Y.V.; Matyjasik, S.; Tseitlin, M.; Roth, M. Specific features of the pyroelectric properties of actual $\mathrm{RbTiOPO}_{4}$ single crystals in the temperature range 4.2-300 K. Phys. Solid State 2008, 50, 1315. [CrossRef]

17. Wang, C.-R.; Pan, Q.-K.; Chen, F.; Lanskii, G.; Nikolaev, N.; Mamrashev, A.; Andreev, Y.; Meshalkin, A. Phase-matching in KTP crystal for THz wave generation at room temperature and $81 \mathrm{~K}$. Infrared Phys. Technol. 2019, 97, 1-5. [CrossRef]

18. Shaldin, Y.V.; Matyjasik, S.; Rabadanov, M.K.; Angert, N.; Roth, M.; Tseitlin, M. Pyroelectric properties of high-resistant $\mathrm{KTiOPO}_{4}$ crystals in the temperature range 4.2-300 K. Phys. Solid State 2006, 48, 912-918. [CrossRef]

19. Sorokina, N.; Voronkova, V. Structure and properties of crystals in the potassium titanyl phosphate family: A review. Crystallogr. Rep. 2007, 52, 80-93. [CrossRef]

20. Bach, F.; Mero, M.; Pasiskevicius, V.; Zukauskas, A.; Petrov, V. High repetition rate, femtosecond and picosecond laser induced damage thresholds of $\mathrm{Rb}: \mathrm{KTiOPO}_{4}$ at $1.03 \mu \mathrm{m}$. Opt. Mater. Express 2017, 7, 744-750. [CrossRef]

21. Morris, P.A.; Crawford, M.K.; Ferretti, A.; French, R.H.; Roelofs, M.G.; Bierlein, J.D.; Brown, J.B.; Loiacono, G.M.; Gashurov, G. Defects in $\mathrm{KTiOPO}_{4}$. MRS Proc. 1989, 152, 95. [CrossRef] 
22. Morris, P.A.; Ferretti, A.; Bierlein, J.D.; Loiacono, G. Reduction of the ionic conductivity of flux grown $\mathrm{KTiOPO}_{4}$ crystals. J. Cryst. Growth 1991, 109, 361-366. [CrossRef]

23. Vekilov, P.; Vekilov, P.G. Two-step mechanism for the nucleation of crystals from solution. J. Cryst. Growth 2005, 275, 65-76. [CrossRef]

24. Tang, L.; Lin, Z.; Hu, Z.; Wang, G. Growth and spectral properties of $\mathrm{Nd}^{3+}: \mathrm{KLu}\left(\mathrm{WO}_{4}\right)_{2}$ crystal. J. Cryst. Growth 2005, 277, 228-232. [CrossRef]

25. Sadhasivam, S.; Perumal, R.N. High temperature molten flux growth, structural and optical characteristics of $\mathrm{KTiOPO}_{4}: \mathrm{Ho}_{\text {and }} \mathrm{KTiOPO}_{4}$ :Er single crystals. J. Cryst. Growth 2019, 512, 152-158. [CrossRef]

26. Gubal, A.; Ganeev, A.; Bodnar, V.; Solovyev, N.; Lyalkin, Y.; Glumov, O.; Yakobson, V. Direct determination of oxygen and other elements in non-conducting crystal materials by pulsed glow discharge time-of-flight mass spectrometry with potassium titanyl phosphate as an example. Vacuum 2018, 153, 248-253. [CrossRef]

27. Detcheva, A.; Gentscheva, G.; Havezov, I.; Ivanova, E. Slurry sampling ETAAS determination of sodium impurities in optical crystals of potassium titanyl phosphate and potassium gadolinium tungstate. Talanta 2002, 58, 489-495. [CrossRef]

28. Hao, X.; Jin, C. Nonstoichiometry in KTP and Nb: KTP crystals by high-temperature solutions method. J. Nonlinear Opt. Phys. Mater. 2015, 24, 1550043. [CrossRef]

29. Ke, Y.; Sun, Y.; Lin, P.; Zhou, J.; Xu, Z.; Cao, C.; Yang, Y.; Hu, S. Quantitative determination of rare earth elements in scheelite via LA-ICP-MS using REE-doped tungstate single crystals as calibration standards. Microchem. J. 2019, 145, 642-647. [CrossRef]

30. Riekstina, D.; Skvortsova, V.; Veveris, O. Application of INAA for investigation of magnesium and aluminium oxide materials. J. Radioanal. Nucl. Chem. 2013, 298, 1907-1911. [CrossRef]

31. Ganeev, A.; Gubal, A.; Korotetski, B.; Bogdanova, O.; Burakov, B.; Titova, A.; Solovyev, N.; Ivanenko, N.; Drobyshev, E.; Iakovleva, E.; et al. Direct isotope analysis of Chernobyl microparticles using time-of-flight mass spectrometry with pulsed glow discharge. Microchem. J. 2017, 132, 286-292. [CrossRef]

32. Ganeev, A.; Gubal, A.; Chuchina, V.; Lyalkin, Y.; Glumov, O.; Yakobson, V.; Solovyev, N. Neon plasma for effective ionisation of oxygen and fluorine in pulsed glow discharge-high ionisation energy elements' quantification in potassium titanyl phosphate single crystals. J. Anal. Atom. Spectrom. 2019, 34, 588-597. [CrossRef]

33. Glumov, O.V.; Bodnar, V.A.; Mel'nikova, N.A.; Yakobson, V.E.; Murin, I.V. Electrical conductivity of potassium titanyl phosphate $\mathrm{KTiOPO}_{4}$ pure crystals and those doped with $\mathrm{Na}^{+}, \mathrm{Rb}^{+}$, and $\mathrm{F}^{-}$ions. Russ. J. Electrochem. 2017, 53, 846-851. [CrossRef]

34. Chuchina, V.; Gubal, A.; Lyalkin, Y.; Glumov, O.; Trefilov, I.; Sorokina, A.; Savinov, S.; Solovyev, N.; Ganeev, A. A study of matrix and admixture elements in fluorine-rich ionic conductors by pulsed glow discharge mass spectrometry. Rapid Commun. Mass Spectrom. 2020, 34, e8786. [CrossRef] [PubMed]

35. Bodnar, V.; Ganeev, A.; Gubal, A.; Solovyev, N.; Glumov, O.; Yakobson, V.; Murin, I. Pulsed glow discharge enables direct mass spectrometric measurement of fluorine in crystal materials-Fluorine quantification and depth profiling in fluorine doped potassium titanyl phosphate. Spectrochim. Acta Part B At. Spectrosc. 2018, 145, 20-28. [CrossRef]

36. Pujol, C.; Aguiló, M.; Díaz, F.; Zaldo, C. Growth and characterisation of monoclinic $\mathrm{KGd}_{1-\mathrm{x}} \mathrm{RE}_{\mathrm{x}}\left(\mathrm{WO}_{4}\right)_{2}$ single crystals. Opt. Mater. 1999, 13, 33-40. [CrossRef]

37. Yakobson, V.E.; Voĭtsekhovski1̌, V.N. Morphology of $\{100\}$ and $\{201\}$ faces and the optical quality of $\mathrm{KTiOPO}_{4}$ crystals. Crystallogr. Rep. 2009, 54, 675-682. [CrossRef]

(C) 2020 by the authors. Licensee MDPI, Basel, Switzerland. This article is an open access article distributed under the terms and conditions of the Creative Commons Attribution (CC BY) license (http://creativecommons.org/licenses/by/4.0/). 